\title{
Analisis Kesalahan Newman dalam Menyelesaikan Soal Cerita Materi Turunan pada Siswa Kelas XII
}

\author{
Nurul Wahidatul Fitri ${ }^{1}$, Sri Subarinah ${ }^{2}$, Muhammad Turmuzi ${ }^{3}$ \\ 1,2,3 Pendidikan Matematika, FKIP, Universitas Mataram, Mataram \\ e-mail: nwfidah02@gmail.com
}

\begin{tabular}{l} 
INFORMASI ARTIKEL \\
\hline Keywords: \\
Error Analysis; Errors \\
Based on Newman's \\
Method; Derivative \\
Word Problem. \\
Kata Kunci: \\
Analisis kesalahan; \\
Kesalahan \\
Berdasarkan Metode \\
Newman; Soal Cerita \\
Turunan. \\
Cara Mengutip: \\
Fitri, N.W., Subarinah, \\
S., \& Turmuzi, M. \\
(2019). Analisis \\
Kesalahan Newman \\
dalam Menyelesaikan \\
Soal Cerita Materi \\
Turunan pada Siswa \\
Kelas XII. Mandalika \\
Mathematics and \\
Education Journal, \\
1(2), 66-73. \\
\end{tabular}

\begin{abstract}
This study was conducted to determine each character of Newman's error and its percentage on student class XII MAN 2 Mataram in academic year 2018/2019. Students' errors found through analyzing students answer in solving story question material of derivative. Based on the result of data analyzed and interview which has been done, it showed that no one of the students can answer all of the questions correctly. The population of this study was 215 students and the sample was 32 students. Analysis technique used for this study was descriptive analysis. Based on the result of the data, it can be found that reading error was on the lowest percentage that is $23 \%$. Error in comprehension and transformation was on the medium percentage those are $44 \%$ and $49 \%$. Error in processing skill was on the lower percentage that is $29 \%$. The last is encoding error was on the highest percentage that is $78 \%$.
\end{abstract}

\begin{abstract}
ABSTRAK
Penelitian ini bertujuan untuk mengetahui kriteria masingmasing jenis kesalahan Newman dan persentasenya pada siswa kelas XII MAN 2 Mataram tahun pelajaran 2018/2019. Kesalahan-kesalahan siswa diketahui melalui analisis terhadap jawaban siswa dalam menyelesaikan soal cerita turunan. Berdasarkan hasil analisis data dan wawancara yang telah dilakukan menunjukkan bahwa tidak ada siswa yang dapat menjawab dengan benar semua soal yang telah diberikan. Populasi penelitian sebanyak 215 siswa dengan sampel penelitian 32 siswa. Teknik analisis yang digunakan adalah analisis deskriptif. Dari hasil penelitian diperoleh, bahwa kesalahan membaca berada dalam kriteria sangat rendah dengan persentase $23 \%$. Kesalahan memahami soal dan transformasi berada dalam kriteria sedang dengan persentase berturut-turut $44 \%$ dan 49\%. Kesalahan keterampilan proses berada dalam kriteria rendah dengan persentase 29\%. Dan kesalahan penulisan jawaban berada dalam kriteria sangat tinggi dengan persentase sebesar $78 \%$.
\end{abstract}

\section{Pendahuluan}

Pendidikan merupakan salah satu sarana strategis untuk meningkatkan kualitas suatu bangsa, karenanya kemajuan suatu bangsa dapat diukur dari kemajuan pendidikannya. Salah satu pelajaran yang wajib dipelajari di dunia pendidikan 
mulai dari SD sampai SMA bahkan sampai jenjang perguruan tinggi adalah matematika. Siswa memerlukan matematika untuk memenuhi kebutuhan praktis serta dapat menggunakan matematika dan pola pikir matematika dalam kehidupan sehari-hari. Aplikasi dari hal tersebut adalah dengan diberikannya soal matematika dalam pemecahan masalah. Salah satu cara untuk melatih kemampuan siswa dalam pemecahan masalah adalah dengan pemberian soal cerita.

Keterampilan menyelesaikan soal cerita menjadi sangat penting untuk dikembangkan pada pembelajaran matematika di sekolah karena dalam tingkatan lebih tinggi semua aplikasi matematika dalam bidang lain selalu melibatkan pemodelan matematika. Model matematika memiliki peran penting dalam membantu siswa lebih memahami proses merubah keadaan nyata ke dalam bahasa matematika. Penyelesaian soal cerita dapat membantu siswa untuk memperoleh pendidikan yang penuh informasi dan melatih siswa berfikit kritis. Walaupun keterampilan siswa dalam menyelesaikan soal cerita memegang peranan yang begitu penting, akan tetapi soal cerita bukan hal yang mudah bagi siswa untuk mengerjakannya dan juga bukan hal mudah bagi guru untuk mengajarkannya, sebagaimana yang dikatakan oleh Davis \& Mc Killip [1] bahwa banyak guru yang merasa tidak terlalu berhasil mengajarkan permasalahan yang berkaitan dengan soal cerita, banyak pula siswa yang menemukan permasalahan soal cerita yang menjadi tantangan paling sulit dalam matematika dan siswa tidak menyukainya.

Materi turunan adalah salah satu materi matematika kelas XI SMA/MAN yang memiliki cakupan penerapan yang cukup luas baik dalam matematika itu sendiri, maupun dalam cabang-cabang ilmu lain seperti dalam bidang sains, teknologi, ekonomi dan sebagainya. Untuk mampu menerapkan materi turunan dalam bidang ilmu lain, maka kemampuan siswa menyelesaikan masalah pada materi turunan ini penting untuk dikembangkan. Kemampuan siswa menyelesaikan masalah dalam matematika dapat dilatih dalam berbagai bentuk soal terutama soal yang disajikan dalam bentuk soal cerita. Penguasaan siswa kelas XII MAN 2 Mataram terhadap materi turunan belum cukup memadai. Hal ini terlihat dari rata-rata nilai ulangan harian siswa kelas XII MAN 2 Mataram yang disajikan pada Tabel 1.

Tabel 1. Rata-rata nilai ulangan harian matematika siswa materi turunan kelas XI MIA MAN 2 Mataram tahun pelajaran 2017/2018

\begin{tabular}{cccc}
\hline No & Kelas & $\begin{array}{c}\text { Rata-rata Nilai } \\
\text { Kelas }\end{array}$ & $\begin{array}{c}\text { Ketuntasan klasikal } \\
(\%)\end{array}$ \\
\hline 1 & XI MIA.1 & 62,16 & 38,64 \\
\hline 2 & XI MIA.2 & 56,34 & 28,57 \\
\hline 3 & XI MIA.3 & 58,60 & 23,26 \\
\hline 4 & XI MIA.4 & 72,93 & 64,29 \\
\hline 5 & XI MIA.5 & 63,82 & 45,45 \\
\hline \multicolumn{4}{c}{ Sumber: Data nilai guru matematika kelas XI MAN 2 Mataram, 2017 }
\end{tabular}

Berdasarkan Tabel 1. dapat dilihat ketuntasan klasikal yang masih belum mencapai $85 \%$. Hal ini menunjukkan masih banyak siswa yang menyelesaikan 
soal turunan dengan tidak tepat. Dengan kata lain, banyak siswa melakukan kesalahan dalam menyelesaikan soal yang diberikan. Berdasarkan hasil wawancara dengan guru bahwa sebagian besar siswa mengalami kesulitan jika dihadapkan dengan soal yang berkaitan dengan soal cerita. Begitupun dengan soal cerita pada materi turunan. Hal tersebut di sebabkan karena dalam soal cerita turunan menuntut siswa untuk menguasai banyak materi-materi penunjang. Selain itu, penyebab umum siswa melakukan kesalahan dalam menyelesaikan soal pada materi turunan khususnya soal cerita adalah kesulitan siswa memodelkan suatu masalah kedalam model matematika, kesalahan siswa dalam melakukan perhitungan, penguasaan materi penunjang mengenai konsep-konsep matematika terbatas dan tidak menuliskan kesimpulan dari jawaban yang diperoleh.

Kesalahan siswa dalam menyelesaikan soal pada materi turunan harus segera diatasi. Untuk itu perlu diketahui kesalahan-kesalahan apa saja yang dilakukan siswa dalam menyelesaikan soal-soal tersebut selanjutnya dianalisis. Jawaban siswa yang akan dianalisis adalah jawaban siswa kelas XII MIA dalam menyelesaikan soal cerita pada materi turunan. Kesalahan-kesalahan yang sudah mampu diketahui dapat dijadikan pertimbangan bagi guru dan calon guru dalam menentukan langkah pembelajaran yang tepat untuk mengurangi kesalahankesalahan siswa dalam menyelesaikan soal-soal terkait dengan turunan sehingga mereka tidak akan mengulangi kesalahan yang sama dan hasil belajar mereka dapat menjadi lebih baik. Hal ini sesuai dengan yang dikatakan Nurkencana dan Sunartana [2]. bahwa kesalahan-kesalahan yang dilakukan siswa perlu untuk dianalisa lebih lanjut agar mendapatkan gambaran tentang kelemahankelemahan siswa yang dites yang selanjutnya dapat digunakan sebagai bahan pertimbangan pengajaran dalam usaha meningkatkan kegiatan belajar mengajar.

Analisis kesalahan Newman adalah salah satu metode yang digunakan untuk menganalisis kesalahan siswa dalam menyelesaikan soal yang berkaitan dengan soal cerita. Menurut Prakitipong \& Nakamura [3] bahwa prosedur Newman adalah suatu metode analisis kesalahan dalam masalah yang berkaitan dengan soal cerita. Hal tersebut sejalan menurut Newman sebagaimana dikutip oleh Karnasih [4] bahwa NEA dikembangkan untuk membantu guru ketika berhadapan dengan siswa yang mengalami kesulitan dengan masalah soal cerita matematis. White [5] juga mengatakan bahwa NEA dirancang sebagai prosedur diagnosis soal cerita sederhana. NEA adalah asesmen diagnosis dan perangkat pengajar yang kuat.

Berdasarkan uraian di atas, tujuan dari penelitian ini adalah menganalisis jawaban siswa kelas XII MAN 2 Mataram tahun pelajaran 2018/2019 dalam menyelesaikan soal cerita pada materi turunan untuk mengetahui kriteria pada masing-masing jenis kesalahan dan persentasenya berdasarkan metode Newman.

\section{Metode}

Jenis penelitian ini adalah penelitian kualitatif dengan pendekatan deskriptif. Penelitian ini dilaksanakan di MAN 2 Mataram dengan ukuran sample 32 siswa dari 215 populasi siswa kelas XII MIA MAN 2 Mataram tahun pelajaran 2018/2019 yang diambil menggunakan teknis proportional stratified random sampling. Instrumen yang digunakan adalah tes uraian dan pedoman wawancara. Teknik analisis yang digunakan dalam penelitian ini adalah analisis deskriptif. 
Untuk mengetahui kesalahan-kesalahan yang dilakukan siswa, data yang telah diperoleh disesuaikan dengan indikator kesalahan. Selanjutnya ditentukan kesalahan yang dilakukan siswa berdasarkan klasifikasi kesalahan Newman.

Untuk mengetahui kriteria kesalahan, dicari persentase kesalahan yang dilakukan siswa terlebih dahulu, selanjutnya ditentukan kriteria kesalahan yang dilakukan dengan merujuk pada kriteria kesalahan yang telah ditetapkan. Rumus yang digunakan untuk mencari persentase kesalahan masing-masing siswa dan semua siswa adalah sebagai berikut:

$$
P_{i j}=\frac{n_{i j}}{N_{i j}} \times 100 \% \operatorname{dan} P_{j}=\frac{\sum n_{i j}}{N_{j}} \times 100 \%
$$

Dengan $P_{i j}=$ Persentase kesalahan siswa ke-i pada jenis $j, i=1$ (siswa ke-1), 2 (siswa ke-2), 3 (siswa ke-3)... 32 (siswa ke-32), $j=1$ (reading errors), 2 (comprehension errors), 3 (transformation errors), 4 (process skill errors), 5 (encoding errors), $n_{i j}=$ Skor kesalahan yang dilakukan siswa ke- $i$ pada jenis $j$ untuk semua soal. $N_{i j}=$ Skor total kemungkinan kesalahan yang dilakukan setiap siswa pada jenis $j$ untuk semua soal, $P_{j}=$ Persentase kesalahan semua siswa jenis j. $\sum n_{i j}=$ Jumlah skor kesalahan yang dilakukan siswa ke- $i$ jenis $j$ untuk semua soal, dan $N_{j}=$ Skor total kemungkinan kesalahan yang dilakukan setiap siswa pada jenis $j$ untuk semua soal [6]. Kriteria kesalahan yang telah ditetapkan sebagaimana terlihat pada tabel di bawah ini.

Tabel 2. Kriteria Kesalahan Siswa

\begin{tabular}{cccc}
\hline NO & \multicolumn{2}{c}{ Interval (\%) } & Kriteria \\
\hline 1 & $75<P_{i j} \leq 100$ & $75<P_{j} \leq 100$ & Sangat tinggi \\
\hline 2 & $58<P_{i j} \leq 75$ & $58<P_{j} \leq 75$ & Tinggi \\
\hline 3 & $42<P_{i j} \leq 58$ & $42<P_{j} \leq 58$ & Sedang \\
\hline 4 & $25<P_{i j} \leq 42$ & $25<P_{j} \leq 42$ & Rendah \\
\hline 5 & $0<P_{i j} \leq 25$ & $0<P_{j} \leq 25$ & Sangat rendah \\
\hline
\end{tabular}

\section{Hasil dan Pembahasan}

Berdasarkan jawaban siswa dalam mengerjakan tes yang diberikan, ditemukan kesalahan-kesalahan yang dilakukan oleh siswa kelas XII MAN 2 Mataram tahun pelajaran 2018/2019. Berikut tabel kriteria jenis kesalahan yang dilakukan siswa MAN 2 Mataram dalam menyelesaikan soal cerita turunan.

Tabel 3. Kriteria Masing-masing Jenis Kesalahan Semua Siswa dalam Menyelesaikan Soal Cerita turunan

\begin{tabular}{llccc}
\hline No & Jenis-Jenis Kesalahan & $\begin{array}{c}\text { Skor Total } \\
\text { Kesalahan } \\
\text { Semua Siswa }\end{array}$ & $\begin{array}{c}\text { Persentase } \\
\text { Kesalahan }\end{array}$ & Kriteria \\
\hline 1 & Kesalahan Membaca Soal ( R ) & 111 & $23 \%$ & $\begin{array}{c}\text { Sangat } \\
\text { Rendah }\end{array}$ \\
\hline 2 & Kesalahan Memahami soal ( C ) & 426 & $44 \%$ & Sedang \\
\hline 3 & Kesalahan Transformasi ( T ) & 233 & $49 \%$ & Sedang \\
\hline
\end{tabular}




\begin{tabular}{llccc}
\hline No & \multicolumn{1}{c}{ Jenis-Jenis Kesalahan } & $\begin{array}{c}\text { Skor Total } \\
\text { Kesalahan } \\
\text { Semua Siswa }\end{array}$ & $\begin{array}{c}\text { Persentase } \\
\text { Kesalahan }\end{array}$ & Kriteria \\
\hline 4 & $\begin{array}{l}\text { Kesalahan Keterampilan Proses } \\
(\mathrm{P})\end{array}$ & 694 & $29 \%$ & Rendah \\
\hline 5 & $\begin{array}{l}\text { Kesalahan Penulisan Jawaban } \\
(\mathrm{E})\end{array}$ & 377 & $78 \%$ & $\begin{array}{c}\text { Sangat } \\
\text { Tinggi }\end{array}$ \\
\hline
\end{tabular}

Selain kriteria jenis kesalahan untuk semua siswa, kriteria kesalahan untuk tingkat kemampuan siswa juga dapat dilihat pada tabel di bawah ini.

Tabel 4. Kriteria Kesalahan Berdasarkan Kemampuan Tinggi, Sedang dan Rendah Siswa

\begin{tabular}{|c|c|c|c|c|c|}
\hline No & $\begin{array}{c}\text { Tingkat } \\
\text { Kemampuan } \\
\text { Siswa }\end{array}$ & Jenis Kesalahan & $\begin{array}{l}\text { Total } \\
\text { Skor }\end{array}$ & $\begin{array}{l}\text { Persentase } \\
\text { Kesalahan }\end{array}$ & $\begin{array}{l}\text { Kriteria } \\
\text { Kesalahan }\end{array}$ \\
\hline \multirow{5}{*}{1} & \multirow{5}{*}{ Tinggi } & Reading Errors & 12 & $16 \%$ & Sangat rendah \\
\hline & & Comprehension errors & 64 & $43 \%$ & Sedang \\
\hline & & Transformation errors & 30 & $40 \%$ & Rendah \\
\hline & & Process skill errors & 83 & $22 \%$ & Sangat Rendah \\
\hline & & Encoding errors & 54 & $72 \%$ & Tinggi \\
\hline \multirow{5}{*}{2} & \multirow{5}{*}{ Sedang } & Reading Errors & 71 & $23 \%$ & Sangat rendah \\
\hline & & Comprehension errors & 303 & $48 \%$ & Sedang \\
\hline & & Transformation errors & 158 & $50 \%$ & Sedang \\
\hline & & Process skill errors & 471 & $30 \%$ & Rendah \\
\hline & & Encoding errors & 198 & $63 \%$ & Tinggi \\
\hline \multirow{5}{*}{3} & \multirow{5}{*}{ Rendah } & Reading Errors & 25 & $28 \%$ & Rendah \\
\hline & & Comprehension errors & 58 & $32 \%$ & Rendah \\
\hline & & Transformation errors & 43 & $48 \%$ & Sedang \\
\hline & & Process skill errors & 132 & $29 \%$ & Rendah \\
\hline & & Encoding errors & 61 & $68 \%$ & Tinggi \\
\hline
\end{tabular}

Berdasarkan Tabel 3 secara keseluruhan siswa kelas XII MAN 2 Mataram melakukan semua jenis kesalahan berdasarkan klasifikasi Newman. Kesalahan yang paling banyak dilakukan oleh siswa adalah kesalahan penulisan jawaban dengan persentase $78 \%$. Kesalahan tersebut masuk dalam kriteria sangat tinggi, karena berkisar antara $75 \%-100 \%$. Kesalahan selanjutnya yang dilakukan paling banyak adalah kesalahan transformasi dengan persentase $49 \%$ kriteria sedang, kesalahan memahami soal dengan persentase $47 \%$ kriteria sedang, kesalahan keterampilan proses dengan persentase 29\% berada dalam kriteria rendah, dan kesalahan membaca soal dengan persentase $23 \%$ kriteria sangat rendah.

Kriteria masing-masing jenis kesalahan dengan mengacu pada metode analisis Newman bahwa jenis kesalahan dengan persentase yang paling kecil yaitu pada jenis kesalahan membaca. Persentase kesalahan membaca sebesar 23\% yang termasuk dalam kriteria sangat rendah. Hasil penelitian ini juga sesuai dengan yang dilakukan oleh Singh yang menyimpulkan persentase kesalahan membaca adalah persentase terkecil diantara 5 klasifikasi kesalahan Newman [7]. 
Berdasarkan Tabel 4 bahwa tingkat kemampuan siswa, baik siswa yang berkemampuan tinggi, sedang maupun rendah memiliki persentase kesalahan membaca paling rendah dibandingkan tahapan kesalahan lain dengan kriteria rendah untuk kemampuan rendah, dan kriteria sangat rendah untuk kemampuan tinggi dan sedang. Ini artinya bahwa semakin tinggi kemampuan siswa, kemampuan membaca siswa semakin baik. Keterangan tambahan yang diperoleh dari hasil wawancara siswa yang melakukan kesalahan pada kesalahan membaca karena diakui bahwa mereka mengetahui kata kunci dalam soal hanya saja beberapa dari mereka masih salah bagaimana menuliskannya dalam bentuk matematika.

Berdasarkan Tabel 3 bahwa kriteria kesalahan memahami soal berada pada kategori sedang. Persentase kesalahan memahami lebih tinggi dibandingkan dengan persentase pada tahapan membaca dengan selisih persentase $21 \%$. Persentase kesalahan memahami soal sebesar $44 \%$ yang termasuk dalam kriteria sedang. Pada Tabel 4 siswa yang berkemampuan sedang memiliki persentase kesalahan memahami paling tinggi dibandingkan dengan kemampuan siswa yang lain. Besarnya persentase kesalahan yang dilakukan oleh siswa yang berkemampun tinggi dan sedang berada pada kriteria sedang. Dan kriteria rendah untuk siswa yang berkemampuan rendah. Akan tetapi selisih persentase ditiap tingkat kemampuan tidak terlalu signifikan.

Penjelasan lebih lanjut dari beberapa subjek wawancara bahwa mereka tidak mengetahui informasi yang seharusnya ditulis pada bagian yang diketahui. Informasi pada bagian yang diketahui yang menyatu dengan kalimat yang ditanyakan kebanyakan tidak dihiraukan dan tidak dituliskan pada bagian yang diketahui. Selain itu, ketidakterbiasaan siswa dalam menuliskan yang diketahui maupun ditanyakan menyebabkan mereka melakukan kesalahan dalam tahap memahami.

Berdasarkan Tabel 3 bahwa kriteria kesalahan tranformasi berada pada kategori sedang. Persentase kesalahan transformasi lebih tinggi dibandingkan dengan persentase pada tahapan memahami dengan selisih persentase 5\%. Persentase kesalahan transformasi sebesar $49 \%$ yang termasuk dalam kriteria sedang. Pada Tabel 4 bahwa kemampuan siswa menggunakan rumus yang tepat sesuai dengan perintah soal dapat dilakukan dengan baik oleh siswa yang berkemampuan tinggi. Hal itu terlihat dari Tabel 4 bahwa siswa yang berkemampuan tinggi memiliki kriteria rendah dibandingkan dengan kemampuan siswa lain yang berkriteria sedang. Ini artinya bahwa semakin tinggi kemampuan siswa, maka kemampuan tranformasi siswa atau kemampuan siswa mengingat dan menggunakan rumus yang digunakan untuk menyelesaikan soal semakin baik. Terungkap dari hasil wawancara adalah siswa yang tidak menuliskan model/rumus yang digunakan memang benar-benar tidak mengetahui model/rumus yang digunakan untuk menyelesaikan soal.

Berdasarkan Tabel 3 bahwa persentase kesalahan keterampilan proses merupakan kedua lebih rendah setelah kesalahan membaca. Persentase kesalahan keterampilan proses sebesar 29\% yang termasuk dalam kriteria rendah. Selisih persentase kesalahan keterampilan proses dengan kesalahan transformasi adalah sebesar 20\%. Dalam hal ini terjadi penurunan persentase kesalahan berdasarkan tahapan Newman. Terjadinya penurunan persentase kesalahan disebabkan karena banyak siswa yang salah menuliskan simbol dari rumus yang digunakan, 
tapi proses yang dilakukan sudah benar. Kemampuan siswa untuk menyelesaikan suatu soal dengan baik sudah dapat dilakukan dengan baik. Pada Tabel 4 bahwa tingkat kemampuan siswa tinggi memiliki kemampuan dalam menyelesaikan atau melakukan process skill dengan baik. Hal tersebut terlihat dari kriteria sangat rendah untuk siswa yang berkemampuan tinggi. Akan tetapi, siswa yang berkemampuan rendah dan sedang berada pada kriteria rendah. Jadi, dalam hal ini, kemampuan siswa baik siswa yang berkemampuan tinggi, sedang maupun rendah memiliki kemampuan process skill yang cukup baik. terungkap dari hasil wawancara bahwa mereka yang tidak melanjutkan prosedur penyelesaian mengaku tidak mengetahui prosedur yang harus dilakukan selanjutnya. Hal ini juga terjadi karena mereka sebelumnya tidak mengetahui operasi matematika/cara yang harus digunakan untuk menyelesaikan soal.

Berdasarkan Tabel 3 bahwa persentase kesalahan penulisan jawaban adalah persentase kesalahan paling tinggi pada setiap persentase kesalahan menurut Newman. Persentase kesalahan penulisan jawaban sebesar $78 \%$ yang termasuk dalam kriteria sangat tinggi. Hal ini serupa dengan hasil temuan Priyanto [5]. bahwa kesalahan penulisan jawaban adalah kesalahan dengan persentase terbesar dibandingkan keempat kriteria kesalahan lainnya dan tergolong kesalahan paling tinggi yang dilakukan oleh siswa kelas VIII SMPN Negeri 10 Jember. Pada Tabel 4 bahwa dari siswa yang berkemampuan tinggi hingga siswa yang berkemampuan rendah memiliki persentase yang besar dengan kriteria kesalahan tinggi. Hal tersebut berarti bahwa semua siswa dalam menuliskan kesimpulan belum cukup baik. ketidakterbiasaan siswa menjadi penyebab besarnya persentase kesalahan. Terungkap dari hasil wawancara bahwa mereka tidak menuliskan kesimpulan karena mereka tidak mampu menemukan jawaban yang diinginkan oleh soal yang menyebabkan tidak mengetahui kesimpulan yang harus dituliskan.

Berdasarkan data tersebut, jenis kesalahan yang paling tinggi diantara semua jenis kesalahan lainnya dengan mengacu pada tahapan analisis menurut Newman adalah pada jenis kesalahan penulisan jawaban (encoding errors) dengan kriteria sangat tinggi.

\section{Penutup}

Berdasarkan hasil penelitian, pembahasan dan mengacu pada tujuan penelitian maka diperoleh kesimpulan bahwa Kriteria masing-masing jenis kesalahan pada tahapan kesalahan membaca persentase 23\% dengan kriteria sangat rendah, kesalahan memahami soal persentase 44\% dengan kriteria sedang, kesalahan transformasi persentase $49 \%$ dengan kriteria sedang, kesalahan keterampilan proses persentase $29 \%$ dengan kategori rendah, dan kesalahan penulisan jawaban persentase $78 \%$ dengan kriteria sangat tinggi.

Kriteria kesalahan untuk tingkat kemampuan siswa pada masing-masing jenis kesalahan yaitu kesalahan membaca memiliki persentase kesalahan sebesar 28\% kriteria rendah, 23\% kriteria sangat rendah, dan 16\% kriteria sangat rendah, berturut-turut pada siswa berkemampuan rendah, sedang dan kemampuan tinggi dengan kriteria. Kesalahan memahami memiliki persentase kesalahan sebesar $32 \%$ kriteria rendah, 48\% kriteria sedang, dan 43\% kriteria sedang, berturut-turut pada siswa berkemampuan rendah, sedang dan kemampuan tinggi. Kesalahan 
transformasi memiliki persentase kesalahan 48\% kriteria sedang, 50\% kriteria sedang dan $40 \%$ kriteria rendah berturut-turut pada siswa berkemampuan rendah, sedang dan kemampuan tinggi. Kesalahan keterampilan proses memiliki persentase kesalahan sebesar 29\% kriteria rendah, 30\% kriteria rendah dan $22 \%$ kriteria sangat rendah berturut-turut pada siswa berkemampuan rendah, sedang dan kemampuan tinggi. Kesalahan menuliskan kesimpulan memiliki persentase kesalahan sebesar 68\% kriteria tinggi, 63\% kriteria tinggi, dan $72 \%$ kriteria tinggi berturut-turut pada siswa berkemampuan rendah, sedang dan kemampuan tinggi. Jenis kesalahan dengan kriteria paling tinggi adalah pada jenis kesalahan penulisan jawaban (encoding errors) dengan persentase $78 \%$ kriteria sangat tinggi.

\section{Referensi}

[1]. Budiyono. (2008). Kesalahan Mengerjakan Soal Cerita Dalam Pembelajaran Matematika. Surakarta: Universitas Sebelas Maret.

[2]. Nurkencana, Wayan dan Sunartana. (2014). Evaluasi Hasil Belajar. Surabaya: Usaha Nasional.

[3]. Prakitipong, Natcha dan Nakamura, Satoshi. (2006). Analysis of Mathematics performance of Grade Five Students in Thailand Using Newman Procedure. Journal of International Cooperation in Education, Vol. 9, No. 1, pp.111-122. Hiroshima: Hiroshima University.

[4]. Karnasih, Ida. (2015). Analisis Kesalahan Newman Pada Soal Cerita Matematis, Vol. 8, No. 1. Jurnal Paradikma: Unimed Medan.

[5]. White, Alan Leslie. (2009). Diagnostic and Pedagogical Issues with Mathematics Word Problem. Brunei International Journal os Science \& Mathematics Education, Vol. 1, No. 1, pp. 100-112.

[6]. Priyanto, Arif., Suharto., dan Trapsilasiwi, Dinawati. (2015). Analisis Kesalahan Siswa dalam Menyelesaikan Soal Cerita Matematika Pokok Bahasan Teorema Phytagoras Berdasarkan Kategori Kesalahan Newman di Kelas VII A SMP Negeri 10 Jember. Jurnal. Jember: Universitas Negeri Jember.

[7]. Farida, Nurul. (2015). Analisis Kesalahan Siswa SMP kelas VIII Dalam Menyelesaikan Masalah Soal Cerita Matematika, Vol. 4, No. 2. Metro: Universitas Muhammadiyah Metro. 